\title{
Data Transcription
}

National Cancer Institute

\section{Source}

National Cancer Institute. Data Transcription. NCI Thesaurus. Code C142497.

The process by which oral source data is transformed into written language. 